\title{
Problem Solving Skills of Students at the Faculty of Sports Sciences
}

\author{
Taner Yilmaz ${ }^{1} \&$ Şihmehmet Yiğit ${ }^{2}$ \\ ${ }^{1}$ Faculty of Sport Sciences, Uşak University, Turkey \\ ${ }^{2}$ School of Physical Education and Sports, Namik Kemal University, Turkey \\ Correspondence: Taner Yilmaz, Faculty of Sport Sciences, Uşak University, Turkey. E-mail: \\ taner.yilmaz@usak.edu.tr
}

Received: January 15, 2020

Accepted: March 30, $2020 \quad$ Online Published: May 30, 2020

doi:10.5539/ies.v13n6p180

URL: https://doi.org/10.5539/ies.v13n6p180

\begin{abstract}
The aim of this study is to determine the problem-solving skills of students studying at the Faculty of Sports Sciences of Uşak University and to examine individuals in terms of their personal variables. 290 students, 85 female and 205 male, participated in the study voluntarily at Uşak University Faculty of Sport Sciences. As a data collection tool in the research; "Personal Information Form" and "Problem Solving Inventory (PSI)" developed by Heppner and Peterson were used to determine problem solving skills.According to the normality test results performed to determine the appropriate analysis method for the data, the p-value for the problem solving scale was greater than 0.05 . The total scores of the problem-solving scale match the normal distribution. For this reason, while investigating the significant differences, the parametric tests; t-test and ANOVA were used.No significant difference was found between the gender, age variable, monthly income level, monthly income level of families, education level of the parents, the region where the students live, the high school variable that the students graduated from, and the total scores of these students' problem solving skills ( $p>0.05)$. As a result, according to the findings; it has been determined that sports have positive effects on the problem solving skills of the students at the Sport Sciences Faculty.
\end{abstract}

Keywords: university student, athlete, problem solving skill

\section{Introduction}

Individuals face a wide variety of problems in their lives. Various definitions of the problem have been made in the literature. These definitions are as follows: Morgan (1991) basically defines the problem as a conflict situation where the individual is faced with inhibition of achieving a goal. Koçel (2003) defines it as obstacles or obstacles that arise while moving in the desired direction. According to Hicks (1991), problem solving is the art of finding new ways to go from where you are to where you want to be. According to another definition, the problem solving process; is to bring together all possible solutions on a subject and therefore it is the demonstration of all professional practices (Taylor, 2000). Problem solving skill (PSS) is a basic skill gained in all areas of life. PSS is an integral part of growth. Human beings begin their problems and problem solution attempts from a very early age. This skill is gained with the help and orientation of the family and the environment before school, and it gains a certain systematic with school life and continues for lifelong process (Aksan, 2006; Yilmaz et al., 2009). The success of the individuals' problem solving depends on their problem solving skill (Ağir, 2007). Problem solving skills are also available for athletes.Sports is a competitive, solidarity and cultural phenomenon that; transforms the natural environment of the individual into the human environment, develops the abilities it acquires, carries out with the rules or under the specific rules, with or without a vehicle, individually or collectively, in the scope of leisure activity or by taking the whole time, socializing, integrating with the society, developing the spirit and physics (Erkal, 1989). In physical education and sports, the values and attitudes, thoughts and abilities of the students have great importance for their sportive success. On the field, in the hall, in the ring and on the wresting, the athlete should be able to adjust his position and the movement to be made according to the position and movement of both the opponent and his teammate (Pulur et al., 2012).

Briefly, the athlete must be able to adjust himself/herself on the field according to the position and movements of the opponent athletes and the positions of his teammates (Aldemir et al., 2014; Günay \& Yücel, 2001). The athlete feels comfortable and free, the self-confidence of the athlete increases and the success is maximized (Baumann, 1994). Sports improves problem solving skills. Sports develops problem solving skills not only for individuals 
without disabilities but also for people with disabilities. Sports in brief; enables the disabled person to develop problem solving skills and to become an intellectual person (Dalbudak, 2020).

The aim of this study is; to determine the problem-solving skills of students studying at the Faculty of Sports Sciences of Uşak University and to examine them in terms of personal variables.

\section{Materials and Methods}

In this part of the research; the research model, population and sample, data collection tools, statistical techniques used are emphasized

\subsection{Model of the Research}

This research, which aims to determine the problem solving skills of the students of the Faculty of Sport Sciences of Uşak University, was carried out using the survey method with the descriptive survey model in order to determine the opinions of the relevant teachers.

\subsection{Population and Sample}

The research group consisted of a total of 290 volunteer students, 85 female and 205 male, studying at the Faculty of Sports Sciences of Uşak University.

\subsection{Data Collection Tools}

As a data collection tool; Personal Information Form and Problem Solving Skills Scale were used.

\subsection{Personal Information Form}

In obtaining the data; regarding the demographic characteristics of the students; The "Personal Information Form" prepared by the researcher, including gender, age, income status of students, educational status of parents, monthly income levels of students, high school information where the student graduated, was used.

\subsection{Problem Solving Skills Scale}

Data related to problem solving skills; "Problem Solving Inventory, Form-A (PSI-A)" developed by Heppner and Petersen (1982) and adapted to Turkish, was collected using the "Problem Solving Inventory (PSI)" by Şahin, Şahin and Heppner (1993). Inventory, which measures the self-perception of the individual about problem solving skills, is a likert type scale with a total of 35 items scored between 1 and 6 . In responding to this, the individual marks how often each item behaves as for those items. The 6-point Likert response options of the inventory are: "I always behave like this", "I mostly behave like this", "I often behave like this ", "I sometimes behave like this", "I rarely behave like this" and "I never behave like this". Some of the items are positive and some of them are negative. The scale gives scores for total scores and subscales. The answers given, are scored between the points 1 and 6. Items 9, 22 and 29 are excluded from the scoring. Scoring is done on 32 items. Items;1, 2, 3, 4, 11, 13, 14, $15,17,21,25,26,30$ ve 34 are scored reversely. The range of points that can be taken from the inventory is between 32 and 192. In the reduction of the total scores obtained from the scale, it is accepted that the person's perception of problem solving skill is positive.

While scoring the sub-scales (Mindful Problem Solving Approach, Self-confident Problem Solving Approach, Evaluative Problem Solving Approach, Planned Problem Solving Approach), which measure the problem-solving approaches that can be described as positive-desired, decreasing the scores, it is evaluated that the related approach styles are used more; as the scores obtained from the sub-scales (Impatient Problem Solving Approach and Avoidance Problem Solving Approach), which measure problem solving approaches that can be described as negative-ineffective, decrease, the related approach styles are used less. (Ferah, 2000).

\section{Data Analysis}

Table 1. Results of normality test for total scores of problem solving skills scale of university students of sports sciences

\begin{tabular}{ccccccc}
\hline \multicolumn{7}{c}{ Kests of Normality $^{\circ}$} \\
\cline { 2 - 7 } & Statistic & Df & Sig. & Statistic & Df & Sig. \\
\hline Toplam puan & .041 & 290 & $.200^{*}$ & .996 & 290 & .602 \\
\hline
\end{tabular}

*. This is a lower bound of the true significance; a. Lilliefors Significance Correction 
According to the normality test results to determine the appropriate analysis method for the data, the p-value for the problem solving scale was greater than 0.05 . The total scores of the problem solving scale match the normal distribution. For this reason, while investigating the significant differences, the parametric tests; t-test and ANOVA were used.

\section{Findings}

When the participants were examined in terms of demographic characteristics, the following findings were reached.

Table 2. The results of the t-test between the total scores of the problem solving skills according to the gender variable of the university students of sports sciences

\begin{tabular}{ccccccc}
\hline Problem Solving & Gender & $\mathrm{N}$ & $\mathrm{X}$ & $\mathrm{SS}$ & $\mathrm{T}$ & $\mathrm{P}$ \\
\hline \multirow{2}{*}{ Total Score } & Male & 205 & 105.6341 & 10.78433 & \multirow{2}{*}{061} & \multirow{2}{*}{.952} \\
& Female & 85 & 105.5529 & 9.31398 & & \\
\hline
\end{tabular}

When the table is analyzed, no significant difference was found between the gender variable of sports science university students and their total problem-solving skills $(\mathrm{p}>0.05)$.

Table 3. The results of the t-test between total scores of problem solving skills according to the age variable of sports sciences university students

\begin{tabular}{ccccccc}
\hline Problem Solving & Age & N & X & SS & T & P \\
\hline \multirow{2}{*}{ Total Score } & $18-23$ & 271 & 105.2878 & 10.28007 & \multirow{2}{*}{1.949} & \multirow{2}{*}{065} \\
& $24-29$ & 19 & 110.2105 & 10.66968 & & \\
\hline
\end{tabular}

When the table is examined, no significant difference was found between the age variable of the sports science university students and their total problem solving skills ( $p>0.05)$.

Table 4. ANOVA test results between sports sciences university students' monthly income levels variable and problem solving skills total score

\begin{tabular}{ccccccc}
\hline Problem Solving & Monthly Income Levels & $\mathrm{N}$ & $\mathrm{X}$ & $\mathrm{SS}$ & $\mathrm{F}$ & $\mathrm{P}$ \\
\hline \multirow{4}{*}{ Total Score } & 1404 and less & 261 & 105.3946 & 10.27363 & & \\
& $1405-2500$ & 21 & 108.7143 & 12.25211 & & \\
& $2501-3500$ & 8 & 104.5000 & 7.01020 & 1.046 & .353 \\
& Total & 290 & 105.6103 & 10.35912 & & \\
\hline
\end{tabular}

When the table is analyzed, there is no significant difference between the monthly income variable of sports science university students and their total problem solving skills $(\mathrm{p}>0.05)$.

Table 5. ANOVA test results between the family monthly income levels variable of the students of sports sciences and their problem solving skills total score

\begin{tabular}{ccccccc}
\hline Problem Solving & Family Monthly Income & N & X & SS & F & P \\
\hline \multirow{5}{*}{ Total Score } & 1404 and less & 75 & 104.7200 & 10.62577 & & \\
& $1405-2500$ & 91 & 104.8791 & 10.15528 & & \\
& $2501-3500$ & 74 & 107.4189 & 10.92817 & & \\
& $3501-4500$ & 31 & 107.1935 & 8.65417 & 1.304 & .269 \\
& 4501 and more & 19 & 103.0000 & 10.14889 & & \\
Total & 290 & 105.6103 & 10.35912 & & \\
\hline
\end{tabular}

When the table is analyzed, no significant difference was found between the family monthly income variable of sport science university students and their total problem solving skills $(\mathrm{p}>0.05)$. 
Table 6. ANOVA test results between father education variable and problem solving skills total score of sports sciences university students

\begin{tabular}{ccccccc}
\hline Problem Solving & Education of father & N & X & SS & F & P \\
\hline \multirow{5}{*}{ Total Score } & İlliterate & 26 & 106.153 & 11.302 & & \\
& Primary school & 115 & 105.000 & 10.602 & & \\
& Secondary school & 62 & 106.790 & 10.273 & & \\
& High school & 62 & 105.612 & 9.913 & .343 & .849 \\
& University/ undergraduate & 25 & 104.920 & 10.049 & & \\
& Total & 290 & 105.610 & 10.359 & & \\
\hline
\end{tabular}

When the table is analyzed, no significant difference was found between the father education variable of sports science university students and their total scores of problem-solving skills ( $\mathrm{p}>0.05)$.

Table 7. ANOVA test results between mother education variable and problem solving skills total score of sports sciences university students

\begin{tabular}{ccccccc}
\hline Problem Solving & Education of Mother & N & X & SS & F & P \\
\hline \multirow{7}{*}{ Total Score } & Illiterate & 76 & 104.815 & 10.844 & & \\
& Primary school & 127 & 105.543 & 10.378 & & \\
& Secondary school & 54 & 106.222 & 10.571 & & \\
& High school & 25 & 106.640 & 8.509 & .249 & .910 \\
& University/ & & & & & \\
& undergraduate & 8 & 106.875 & 11.038 & & \\
& Total & 290 & 105.610 & 10.359 & & \\
\hline
\end{tabular}

When the table is analyzed, no significant difference was found between the mother education variable of sports science university students and their total scores of problem solving skills ( $p>0.05)$.

Table 8. ANOVA test results between the region variable where sports sciences university students live and their problem solving skills total score

\begin{tabular}{lcccccc}
\hline Problem Solving & The Region Where Sports Sciences University Students Live & N & X & SS & F & P \\
& The Marmara Region & 40 & 106.775 & 10.299 & & \\
& Eagen Region & 82 & 105.768 & 10.530 & \\
& Central Anatolian Region & 26 & 105.846 & 8.244 & \\
Total Score & Black Sea region & 28 & 107.464 & 11.133 & & \\
& Mediterranian Region & 30 & 105.866 & 10.441 & & .774 \\
& Eastern Anatolian Region & 28 & 104.642 & 11.807 & \\
& Southeast Anatolian Region & 56 & 103.857 & 10.060 & \\
& Total & 290 & 105.610 & 10.359 & \\
\hline
\end{tabular}

When the table is analyzed, no significant difference was found between the region variable where the students of sports sciences lived and their problem solving skills total score ( $p>0.05)$.

Table 9. ANOVA test results between high school variable graduated by sports science university students and problem solving skills total score

\begin{tabular}{ccccccc}
\hline Problem Solving & graduated high school & N & X & SS & F & P \\
\hline \multirow{4}{*}{ Total Score } & high school & 199 & 105.738 & 10.214 & & \\
& vocational high school & 53 & 105.886 & 10.962 & & \\
& sports high school & 38 & 104.552 & 10.469 & .231 & .794 \\
& Total & 290 & 105.610 & 10.359 & & \\
\hline
\end{tabular}

When the table is analyzed, no significant difference was found between the high school variable graduated by 
sports science university students and the total score of problem solving skills ( $\mathrm{p}>0.05)$.

\section{Discussion and Conclusion}

The aim of the study is to examine the problem-solving skills of the sports science students studying at the university.

No significant difference was found between the gender variable and total problem solving skills of students in the faculty of sports sciences (p>0.05). Pulur et al. (2012), Taylan (1990), Basmaci (1998) did not find a significant difference between their problem solving skills and their gender. It supports the studies and researches we have done. As a result of the research; since problem solving does not affect both genders (male and female), it can be considered that there is no difference.

No significant difference was found between the age variable and total problem solving skills of students in the faculty of sports sciences ( $>>0.05$ ). Demir et al. (2007), Yilmaz et al. (2009) found a similar finding in their study to this study, and it was found that age was not effective on problem solving skills. There was no significant difference between the monthly income variable of students in the faculty of sports sciences and their problem solving skills total score ( $>00.05$ ). Türkçapar (2009) found a similar finding in his study and it was found that monthly income was not effective on problem solving skills. We think that the income level does not affect problem solving skill. No significant difference was found between the monthly income variable of the family and the problem solving skills total score of the students in the faculty of sports sciences ( $p>0.05)$. Çağlayan et al. (2008) found a similar finding in their study to this study, and it was found that the family's monthly income was not effective on problem solving skills. It is thought that they can solve the problems they face more easily regardless of the monthly income level of the family.

No significant difference was found between father education variable and problem solving skills total score of students in faculty of sports sciences ( $>00.05$ ). Güzel (2004), Çağlayan et al. (2008) found a similar finding in their studies, and it was found that father's education was not effective on problem solving skills. It is thought that fathers can easily solve the problems they encounter at any level of education. No significant difference was found between the mother education variable and problem solving skills total score of students in the faculty of sports sciences ( $p>0.05$ ). Çağlayan et al. (2008), Tümkaya and İflazoğlu (2000) found a similar finding in their studies to this study and found that mother's education was not effective on problem solving skills. It is thought that mothers can solve the problems they encounter more easily, regardless of their educational level. No significant difference was found between the region variable where students in the faculty of sports sciences live and problem solving skills total score ( $p>0.05$ ). Yilmaz et al. (2009), Yurttaş and Yetkin (2003) reached a similar finding in their studies related to this study, and it was found that the region where the students live did not have an impact on problem solving skills. It is thought that they can solve the problems they encounter more easily as a result of technological developments.

No significant difference was found between the high school variable graduated by the students in the sports sciences faculty and the problem solving skills ( $>>0.05$ ). Çelik and Yurdakul (2009), Gemlik and Sur (2004), Kelleci and Gölbaşi (2004), Erdem (1995) found a similar finding in their studies, and it was determined that the high school variable that students graduated did not have an effect on problem solving skills. Although they graduate from different schools, it is thought that they can solve the problems they encounter more easily as a result of the developments in education. It was observed that individuals with self-concept (ego) had a lower level of making mistakes and exhibiting aggressive attitude (Yiğit, Yilmaz, Acar, \& Dalbudak, 2019).

As a result, it has been determined that the age, gender, income level of the students, the income level of the family, the education level of the parents, the high school where the student graduates, the region where the students live do not affect the problem-solving skills of the students. It is recommended to conduct research into larger groups and different faculties in order to identify students' problem solving skills and the different factors affecting these skills.

\section{References}

Ağir, M. (2007). Üniversite Öğrencilerinin Bilişsel Çarpitma Düzeyleri ile Problem Çözme Becerileri ve Umutsuzluk Düzeyleri Arasindaki İlişki. Doktora Tezi, İstanbul.

Aksan, N. (2006). Üniversite ögrencilerinin epistemolojik inançlari ile problem çözme becerileri arasindaki ilişki. Yüksek Lisans Tezi, Sosyal Bilimler Enstitüsü, On Sekiz Mart Üniversitesi, Çanakkale.

Aldemir, Y. G., Biçer, T., \& Kale, E. K. (2014). Futbolcularda İmgeleme Çalişmalarinin Problem Çözme Üzerine Etkisi. Spor ve Performans Araştirmalari Dergisi, 5(2), 37-45. https://doi.org/10.17155/spd.05118 
Basmaci, S. K. (1998). Üniversite öğrencilerinin problem çözme becerilerini algilamalarinin bazi değişkenler açisindan incelenmesi (Master's thesis, İnönü Üniversitesi).

Baumann, S. (1994). Uygulamali Spor Psikolojisi (Çev: İkizler C. Özcan A. Ö.). Alfa Basim Yayin Dağitim, İstanbul.

Çağlayan, H. S., Taşğin, Ö., \& Yildiz, Ö. (2008). Spor Yapan Lise Öğrencilerinin Problem Çözme Becerilerinin Çeşitli Değişkenler Açisindan İncelenmesi. Beden Eğitimi ve Spor Bilimleri Dergisi, 2(1), 62-77.

Çelik, C., \& Yurdakul, M. (2009). Hastane Yöneticilerinin Problem Çözme Becerileri: Bir Alan Araştirmasi. Çukurova Üniversitesi Sosyal Bilimler Enstitüsü Dergisi, 18(1), 95-108.

Dalbudak, İ. (2020). 18-20 Yaş Arasi Spor Yapan ve Yapmayan B2 ve B3 Görme Engelli Bireylerin Duygusal Zeka ve Saldirganlik Düzeyleri. Gece Kitapliği, Ankara.

Demir, R., Engin, E., Açikel, E., Örener, C., \& Çağlar, S. (2008). Ege Üniversitesi Tip Fakültesi Hastanesi başhemşirelerinin yönetim becerilerini algilamalari ile problem çözme becerileri arasindaki ilişkinin incelenmesi.

Erdem, Y. (1995). Yüksekokul ve Sağlik Meslek Lisesi Mezunu Hemşirelerin Problem Çözme Becerilerini Algilama Durumlari, 4. Ulusal Hemşirelik Kongresi, Ankara.

Erkal, M. (1986). Sosyolojik Açidan Spor. Milli Eğitim Basimevi, Ankara.

Ferah, D. (2000). Kara Harp Okulu Öğrencilerinin Problem Çözme Becerilerini Algilamalarinin ve Problem Çözme Yaklaşim Biçimlerinin Cinsiyet, Sinif, Akademik Başari ve Liderlik Yapma Açisindan Incelenmesi. Yüksek Lisans, Sosyal Bilimler Enstitüsü, Hacettepe Üniversitesi, Ankara.

Gemlik, N., \& Sur, H. (2004). Özel Hastane Yöneticilerinin Problem Çözme Becerilerini algilama düzeylerine İlişkin Bir İnceleme. Beden Eğitimi ve Spor Bilimleri Dergisi, 11(2).

Günay, M., \& Yüce, İ. (2001). Futbol Antrenmaninin Bilimsel Temelleri. Gazi Kitapevi, Ankara.

Güzel, A. (2004). Marmara Üniversitesi Öğrencilerinin Öğrenme Stilleri İle Problem Çözme Becerileri Arasindaki İlişkinin İncelenmesi. Yüksek Lisans Tezi, Marmara Üniversitesi Eğitim Bilimleri Enstitüsü, Eğitim Bilimleri Anabilim Dali, İstanbul.

Heppner, P. P., \& Petersen, C. H. (1982). The development and implications of a personal problem-solving inventory. Journal of Counseling Psychology, 29(1), 66-75. https://doi.org/10.1037/0022-0167.29.1.66

Hicks, J. M., (1991). Problem Solving in Business and Management. Champman and Hall, London. https://doi.org/10.1007/978-1-4899-7148-7

Kelleci, M., \& Gölbaşi, Z. (2004). Bir Üniversite Hastanesinde Çalişan Hemşirelerin Problem Çözme Becerilerinin Bazi Değişkenler Açisindan İncelenmesi, C.Ü. Hemşirelik Yüksekokulu Dergisi, 8(2).

Morgan, C. T. (1991). Psikolojiye giriş. Ankara: Meteksan Ltd. Şti.

Pulur, A., Karabulut, E. O., \& Hürmüz, K. O. Ç. (2012). Farkli branşlardaki üst düzey üniversiteli sporcularin problem çözme becerilerinin incelenmesi. Spormetre Beden Eğitimi ve Spor Bilimleri Dergisi, 10(1), 1-6. https://doi.org/10.1501/Sporm_0000000213

Şahin, N., Şahin, N. H., \& Heppner, P. P. (1993). The psychometric properties of the problem solving inventory. Cognitive Therapy and Research, 17, 379-396. https://doi.org/10.1007/BF01177661

Taylan, S. (1990). Heppner'in problem çözme envanterinin uygulama, güvenlik ve geçerlilik çalişmalari (Doctoral dissertation, Yüksek Lisans Tezi, Ankara Üniversitesi, Ankara).

Taylor, C. (2000). Clinical problem-solving in nursing: insights from the literature. Journal of Advanced Nursing 31(4), 842-849. https://doi.org/10.1046/j.1365-2648.2000.01342.x

Tümkaya, S., İflazoğlu, A. (2000). Ç.Ü. Sinif Öğretmenliği Öğrencilerinin Otomatik Düşünce ve Problem Çözme Düzeylerinin Bazi Sosyo-Demografik Değişkenlere Göre İncelenmesi. Çukurova Üniversitesi Sosyal Bilimler Dergisi, 6(6), 143-158.

Türkçapar, Ü. (2009). Beden eğitimi spor yüksekokulu öğrencilerinin farkli değişkenler açisindan problem çözme becerileri. Ahi Evran Üniversitesi Kirşehir Eğitim Fakültesi Dergisi (KEFAD), 10(1), 129-139.

Yiğit, Ş., Yilmaz, T., Acar, E., \& Dalbudak, İ. (2019). An Investigation of Self and Aggression Levels of Weightlifters. International Journal of Applied Exercise Physiology, 8(3).

Yilmaz, E., Karaca, F., \& Yilmaz, E. (2009). Sağlik Yüksekokulu Öğrencilerinin Problem Çözme Becerilerinin 
Bazi Değişkenler Açisindan İncelenmesi. Anadolu Hemşirelik ve Sağlik Bilimleri Dergisi, 12(1), 38-48.

Yurttaş, A., \& Yetkin, A. (2003). Sağlik Yüksekokulu öğrencilerinin empatik becerileri ile problem çözme becerilerinin karşilaştirilmasi. Atatürk Üniversitesi Hemşirelik Yüksekokulu Dergisi, 6(1), 1-13.

\section{Copyrights}

Copyright for this article is retained by the author(s), with first publication rights granted to the journal.

This is an open-access article distributed under the terms and conditions of the Creative Commons Attribution license (http://creativecommons.org/licenses/by/4.0/). 